\title{
Population Dynamics and Age Relation- ships of 8 Tree Species in Navajo National Monument, Arizona
}

\author{
J.D. BROTHERSON, S.R. RUSHFORTH, W.E. EVENSON, J.R. JOHANSEN, AND C. MORDEN
}

The presence of 3 major archeological ruins dating from the 11 th to 13th centuries (Woodbury 1963) provided the primary motivation for including Navajo National Monument in the National Parks System. Also included in the monument are some unique ecosystems, especially a small relict of "mountain vegetation" found in Betatakin Canyon. As visitor pressures mount annually, proper management of these unique ecosystems becomes highly important. Since trees are the dominant features of these ecosystems, and are central to management considerations, the present work has examined populations of 8 major tree species in the monument.

The objectives of this study were, first, to develop age prediction equations for tree species growing in Navajo National Monument, and second, to assess the present age profiles, reproductive recruitment, and density relationships of these tree populations. Variations in the growth-ring widths of trees have been used for many years to date wood (Douglas 1935, Glock 1937) and to garner information on past climates (Fritts 1971; Stockton and Meko 1975; Dean and Robinson 1978; Harper 1979). Additionally, ring width variations have been studied to ascertain differences in the environments of selected habitats (Ferguson and Humphrey 1959, Stockton and Fritts 1973, Fritts 1974) and to assess site quality with reference to timber production (State 1966, Brickell 1968, Jones 1969). Although stem diameter measuresments have long been used to predict tree age and ascertain population status, it is difficult to use data from one area to extrapolate to conditions in other areas (Dealy 1975, Brotherson et al. 1980). Because of these difficulties and because of the absence of such data on northeastern Arizona plant communities, our studies provide useful baseline information.

\section{Study Site}

Navajo National Monument is located in Navajo County, northeastern Arizona. The monument supports a tree flora of 14 species (Brotherson et al. 1978). Betatakin Canyon, the largest of the 3 segments of the monument, hosts the greatest variety of tree species. Populus tremuloides (quaking aspen), Quercus gambelii (Gambel oak), Pseudotsuga menziesii (Douglas fir), and Acer negundo (boxelder) are of major importance in the communities of the canyon bottom (Woodbury 1963). Growing with these as understory species are Prunus virginiana (chokecherry) and Betula occidentalis (waterbirch). The plant communities of the canyon bottom represent a small relict of "mountain vegetation" and thus are unique in this predominantly desert region.

Juniperus osteosperma (Utah juniper) and Pinus edulis (pinyon pine) grow abundantly as part of the pigmy woodland (pinyonjuniper community) on the upper slopes of the canyon, the adja\footnotetext{
Authors are associate professors (Brotherson and Rushforth), graduate research
assistants (Johansen and Morden), Department of Botany and Range Science, and professor (Evenson), Department of Physics and Astronomy, Brigham Young University, Provo, Utah 84602.

This study completed as part of contract N. PX7029-9-0570 from the Southwest Region of the National Park Service.

Manuscript received May 22, 1980.
}

cent slickrock areas and the plateau behind the canyon rim (Brotherson et al. 1978). The pigmy woodland community covers more area than any other type in northeastern Arizona.

Gambel oak is the most extensive type in the Monument aside from tne pinyon-juniper community. It is found in all 3 segments of the monument but reaches its greatest development at Keet Steel and Betatakin. Prunus emarginata (bittercherry) also grows at Keet Steel but is uncommon.

The streamside community of the Inscription House segment of the monument contains Populus fremontii (Fremont poplar), Populus angustifolia (narrowleaf cottonwood), Salix goodingii (Gooding willow), Tamarix ramosissima (salt cedar), and Elaegnus angustifolia (Russian olive). Fremont poplar is the dominant tree within this community with salt cedar attaining local importance. All other species are encountered only inf requently.

\section{Methods}

Density data for all species were obtained using the quarter method (Phillips 1959). A total of 40 points were taken for all trees where populations exceeded 160 individuals. Fremont poplar and salt cedar populations numbered less than 160 individuals, so density measurements in these two species are based on fewer sample points.

Tree diameter measurements were taken on all 160 individuals sampled or on all individuals of the population if less than 160 . The diameters were measured at breast height in all species except pinyon pine, Utah juniper, and salt cedar. In these species, diameters were taken 1 foot above the ground. All diameters were measured with a standard diameter tape.

Individual stems were sampled for age determinations using an increment borer in all species except pinyon pine and Utah juniper. The wood of these species was impossible to bore, making it neessary to obtain cross-sections using a chain saw.

Stem cross-sections and/or increment borer corings were selected from each population to provide samples for all size classes. The cross-sections and borings were returned to the laboratory, polished with fine sandpaper and ring-counted twice (independently) with the aid of a binocular microscope (Ferguson 1970). Age determinations were made on the assumption that 1 ring equals 1 year.

Linear regression and regression of log-log transformed data (ie $\log$ age vs. log stem-diameter) were used to analyze all stemdiameter-age relationships. Age prediction equations were then constructed from these relationships (Brotherson et al. 1980). Taxonomy follows McDougall (1973).

\section{Results}

Of the 14 tree species found in the monument only 8 were abundant enough for thorough study. Table 1 includes a list of these species together with their densities, general growth rates, and sample sizes. This table shows that the evergreen species grew slower than the decidous species. This is especially true for Utah 

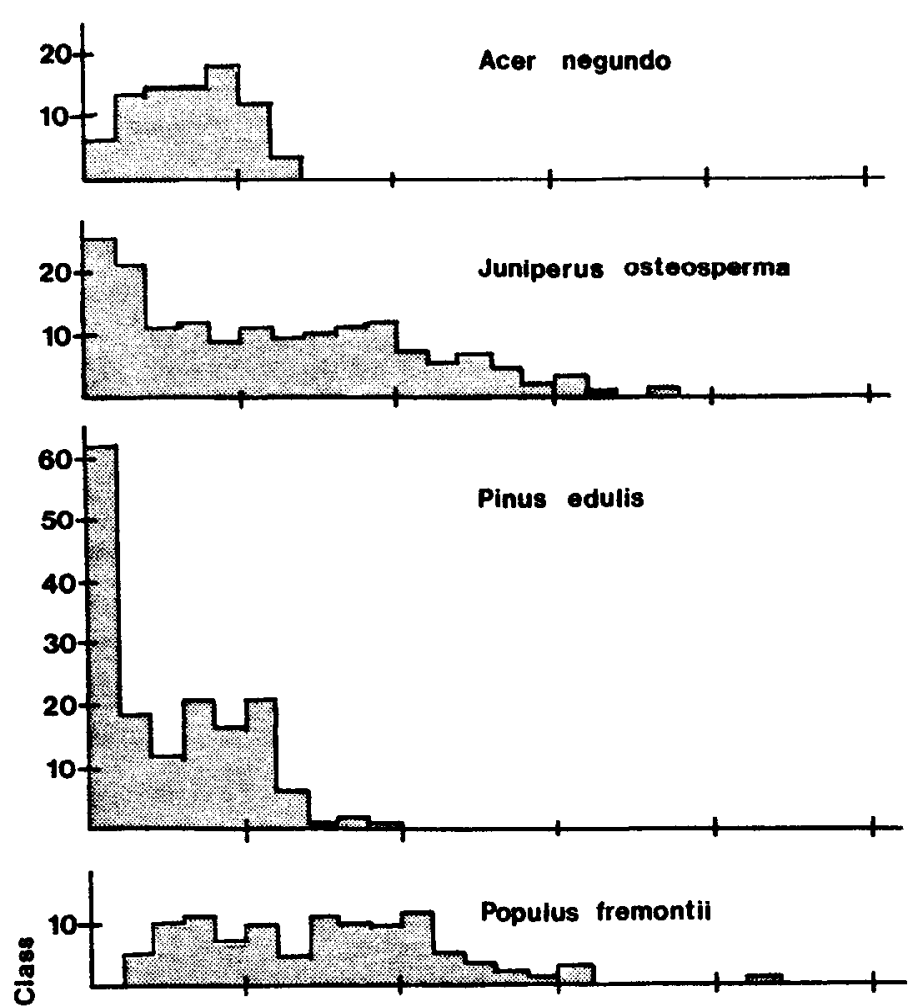

$\frac{8}{6}$
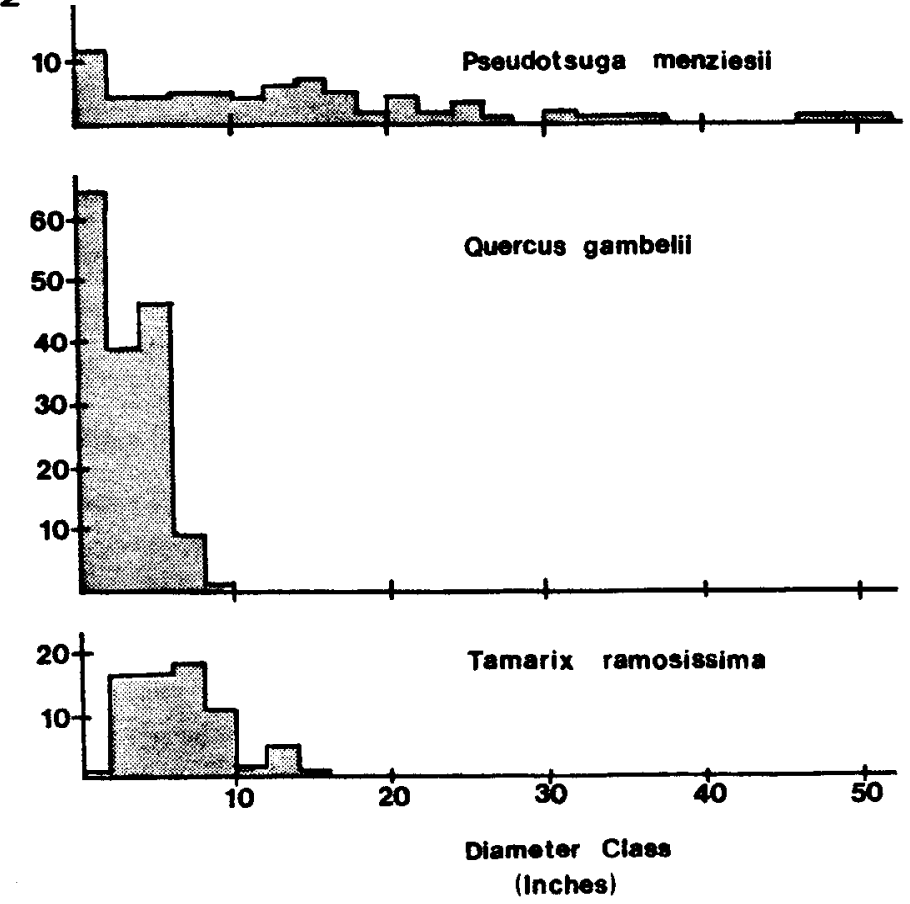

Fig. 1. Population profiles by stem diameter class for 8 tree species.
Table 1. Sample size, density in trees/acre, growth rings/inch, and relative growth rates with respect to Juniperus osteosperma.

\begin{tabular}{lcccc}
\hline \hline Species & $\begin{array}{c}\text { Sample } \\
\text { size }\end{array}$ & $\begin{array}{c}\text { Density } \\
\text { (trees/acre) }\end{array}$ & $\begin{array}{c}\text { Growth } \\
\text { rings/inch }\end{array}$ & $\begin{array}{c}\text { Relative } \\
\text { growth rate }\end{array}$ \\
\hline Acer negundo & 80 & 163 & 22.7 & 4.1 \\
Juniperus osteosperma & 160 & 49 & 93.6 & 1.0 \\
Pinus edulis & 160 & 247 & 79.3 & 1.2 \\
Populus fremontii & 103 & 425 & 4.4 & 21.3 \\
Populus tremuloides & 160 & 502 & 18.5 & 5.1 \\
Pseudotsuga taxifolia & 72 & 50 & 35.9 & 2.6 \\
Quercus gambelii & 160 & 604 & 25.2 & 3.7 \\
Tamarex ramosissima & 72 & 856 & 6.0 & 15.6 \\
\hline
\end{tabular}

'Relative growth rate of Juniperus osteosperma is taken to be one. All other species grow faster (the larger the number the larger the growth).

juniper and pinyon pine. Densities varied from 49 to 50 individuals per acre in Utah juniper and Douglas fir to 856 individuals per acre in salt cedar. Six of the species demonstrated highly clumped distribution patterns with each population occupying discrete habitats. Only Utah juniper and pinyon pine showed dispersion in their distribution patterns.

Population profiles were constructed by size class for all 8 species (Table 2; Fig. 1). Five of the species, Utah juniper, pinyon pine, quaking aspen, Douglas fir and Gambel oak showed stable to expanding populations, while the populations of boxelder, Fremont poplar and salt cedar a re all declining as indicated by low numbers of young trees in their profiles. The decline in the boxelder population is likely due to successional patterns occurring in the bottom of Betatakin Canyon. Boxelder generally occupies rather open sites with abundant sunlight. However, since the establishment of the Monument, there appears to have been a thickening of the canopy causing seedlings of this species to experience difficulty in becoming established. Consistent with this interpretation is the fact that nearly all observed boxelder seedlings were found in the upper end of the canyon where canopy development is least. Conversely, older trees were over-represented where the forest canopy was much more dense. Under-recruitment of seedlings in the Fremont poplar and salt cedar populations is likely due to the fact that both populations are located in the Inscription House segment of the Monument along a small stream where domestic sheep and cattle activity is extremely high. The animals concentrate in the area along the stream for both feeding and shading purposes. The result is that little or no understory vegetation is found in the area. When seedlings of these two species become established, they are eliminated by grazing.

A total of 964 stems of the 8 species studied were sampled for diameter. Eighty percent of the stems were less than 14 inches in diameter. Eighty-eight $(9 \%)$ of the stems were aged using the dissecting microscope and their stem diameters (inches) were plotted against stem age (Figures 2 and 3). Regression equations for age prediction were then generated (Table 3 ). Both linear and $\log$-log transformed functions were used to generate age prediction equations. All correction coefficients ( $r$ values) but one were improved through the use of the log-log transformation. All prediction equations were significant $(p<0.05)$ except those for Fremont poplar.

Estimated ages showed mean deviations from real ages of from 18 to $67 \%$ with the use of linear regression equations and from 14 to $52 \%$ with the use of the log-log transformed equations (Table 4). In the cases of boxelder, Utah juniper, pinyon pine, Fremont poplar and salt cedar, the use of the log-log transformation improved predictive value only slightly over the linear equations. In quaking aspen, Douglas fir and Gambel oak age predictions were much improved by the log-log transformation. The high degree of variation in predicted ages from real ages in Douglas fir comes from the fact that this species grows in a variety of microhabitats which are scattered across a wide spectrum of moisture conditions in Betatakin Canyon. Thus, growth rates are widely different. 

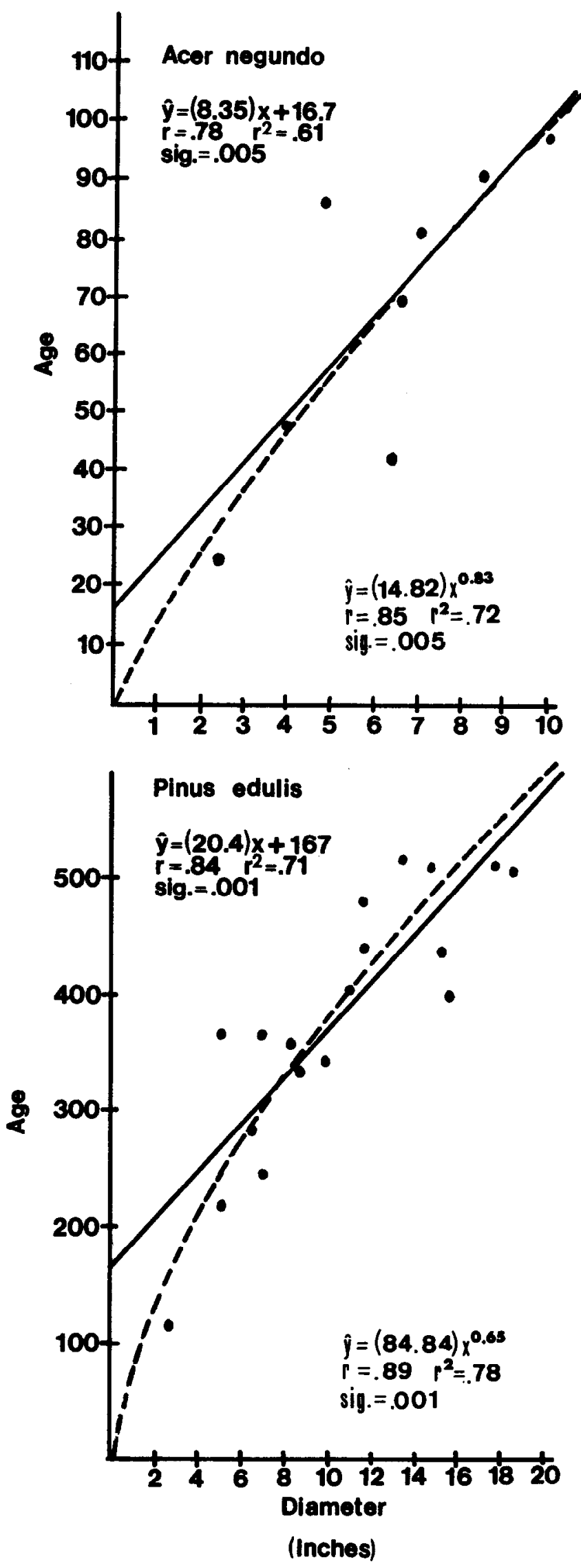

Juniperus osteosperma
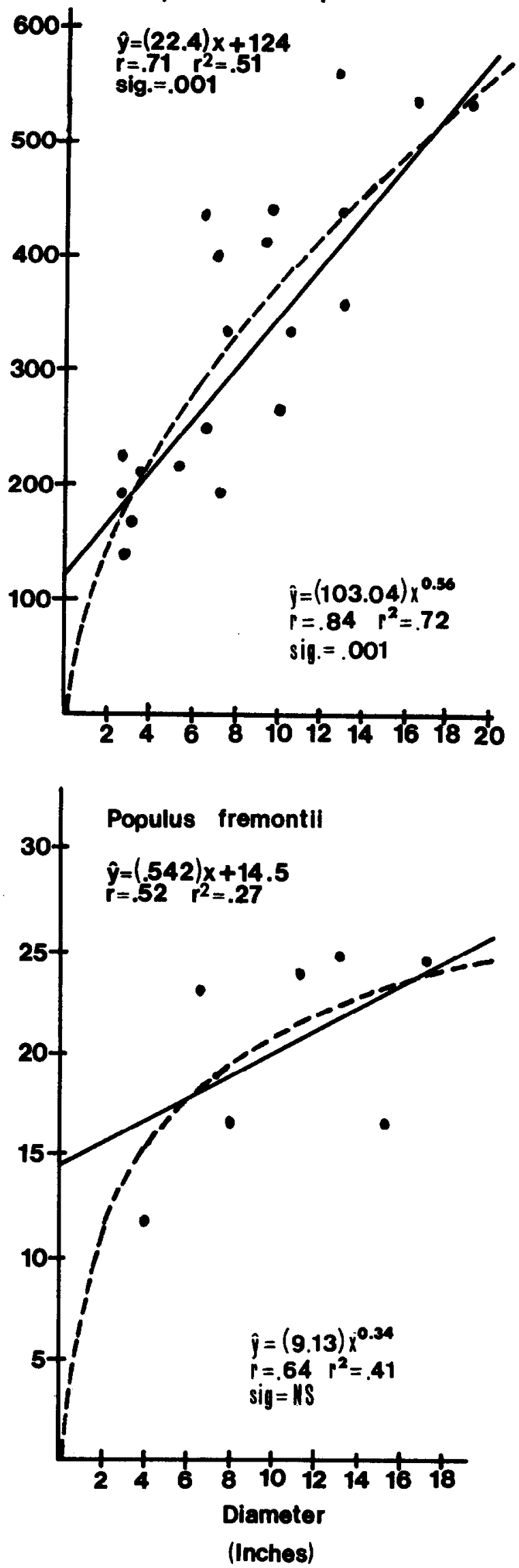

Fig. 2. Stem diameter (inches) and age (1 ring equals 1 year) relationships of 4 tree species. 

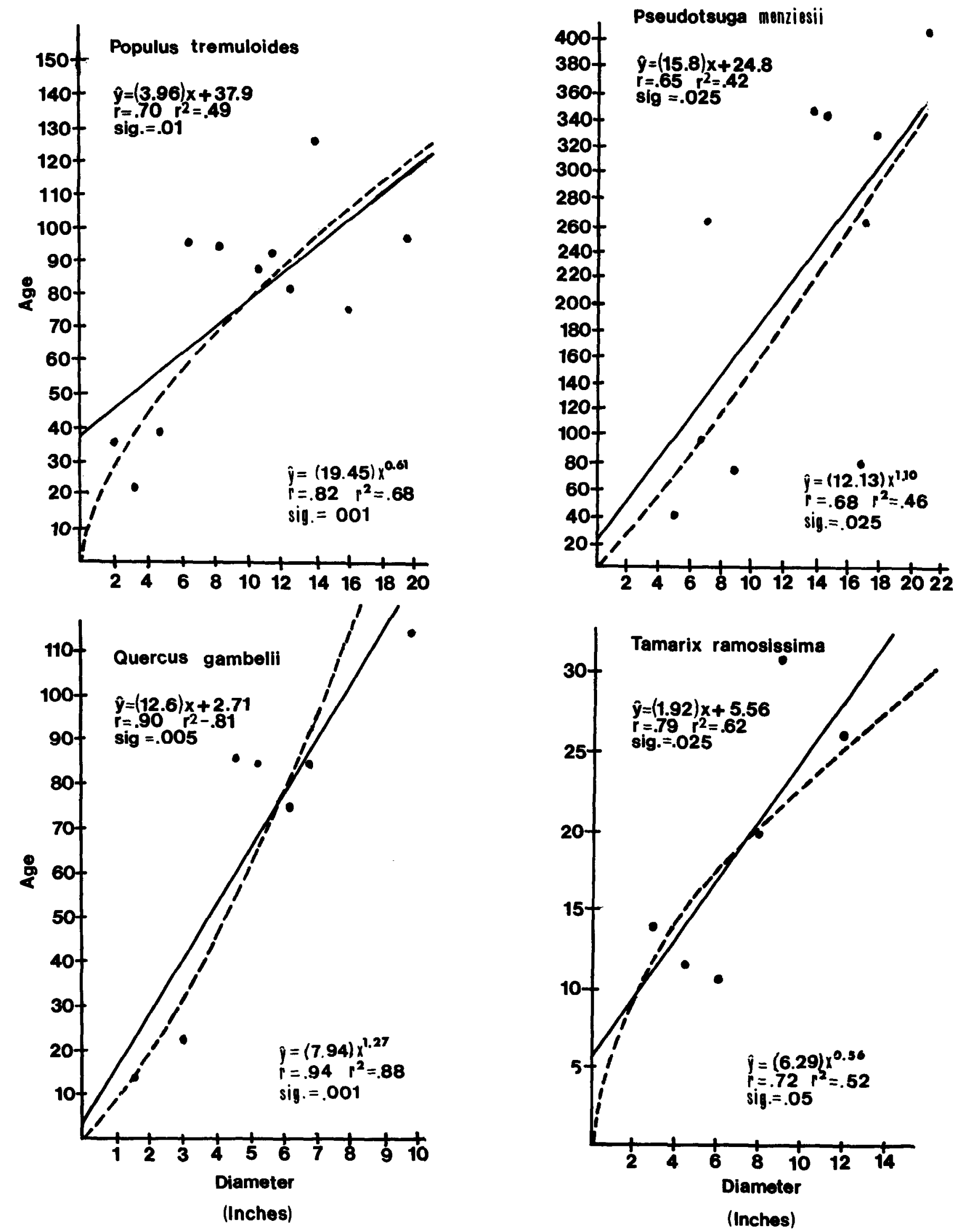

Fig. 3. Stem diameter (inches) and age (I ring equals 1 year) relationships of 4 tree species. 
Table 2. Population profiles represented by the number of individuals sampled in each diameter class for each of the 8 tree species. Diameter classes are designated by their maximum diameter in inches.

\begin{tabular}{|c|c|c|c|c|c|c|c|c|c|c|c|c|c|c|c|c|c|c|c|c|c|c|c|}
\hline & \multicolumn{23}{|c|}{ Diameter class } \\
\hline & 2 & 4 & 6 & 8 & 10 & 12 & 14 & 16 & 18 & 20 & 222 & 242 & 62 & 83 & 303 & 323 & 3436 & 638 & 4042 & 4446 & 48 & & 52 \\
\hline Acer negundo & 6 & 13 & 14 & 14 & 18 & 12 & 3 & & & & & & & & & & & & & & & & \\
\hline Juniperus osteosperma & 26 & 21 & 11 & 12 & 8 & 11 & 9 & 10 & 11 & 12 & 75 & 6 & 4 & 2 & 2 & 3 & 1 & 1 & & & & & \\
\hline Pinus edulis & 62 & 18 & 12 & 21 & 16 & 21 & 6 & I & 2 & 1 & & & & & & & & & & & & & \\
\hline Populus fremontii & 0 & 5 & 10 & 11 & 7 & 10 & 4 & 11 & 10 & 9 & 125 & 3 & 2 & 1 & 1 & 2 & & & & 1 & & & \\
\hline Populus tremuloides & 55 & 39 & 11 & 8 & 3 & 9 & 13 & 8 & 8 & 5 & & & & & & & & & & & & & \\
\hline Pseudotsuga taxifolia & 12 & 4 & 4 & 5 & 5 & 4 & 6 & 7 & 5 & 2 & 42 & 3 & I & & & 2 & 11 & 1 & & & 1 & 1 & 1 \\
\hline Quercus gambelii & 64 & 38 & 46 & 9 & 1 & & & & & & & & & & & & & & & & & & \\
\hline Tamarix ramosissima & 1 & 17 & 17 & 18 & 11 & 2 & 5 & 1 & & & & & & & & & & & & & & & \\
\hline
\end{tabular}

Table 3. Age prediction equations for the 8 tree species along with their correlation coefndents, coefficients of determination, and significance levels. The first equation in each set is from linear regression and the second is from the log-log transformation.

\begin{tabular}{|c|c|c|c|c|c|}
\hline Species & Common name & Age prediction equation & $r$ & $R^{2}$ & \\
\hline Acer negundo & Box elder & $\begin{array}{l}\text { Age }=(8.35)(\text { Diam })+16.7 \\
\text { Age }=(14.82)(\text { Diam })^{0.83}\end{array}$ & $\begin{array}{l}.78 \\
.85\end{array}$ & $\begin{array}{l}.61 \\
.72\end{array}$ & $\begin{array}{l}.005 \\
.005\end{array}$ \\
\hline Juniperus osteosperma & Utah juniper & $\begin{array}{l}\mathrm{Age}=(22.4)(\mathrm{Diam})+124 \\
\mathrm{Age}=(103.04)(\mathrm{Diam})^{0.56}\end{array}$ & $\begin{array}{l}.71 \\
.84\end{array}$ & $\begin{array}{l}.51 \\
.71\end{array}$ & $\begin{array}{l}.001 \\
.001\end{array}$ \\
\hline Pinus edulis & Pinyon pine & $\begin{array}{l}\mathrm{Age}=(20.4)(\mathrm{Diam})+167 \\
\mathrm{Age}=(84.84)(\text { Diam })^{0.65}\end{array}$ & .84 & .71 & $\begin{array}{l}.001 \\
.001\end{array}$ \\
\hline Populus fremontii & Fremont poplar & $\begin{array}{l}\mathrm{Age}=(.542)(\mathrm{Diam})+14.5 \\
\mathrm{Age}=(9.13)(\mathrm{Diam})^{0.34}\end{array}$ & $\begin{array}{l}.52 \\
.64\end{array}$ & $\begin{array}{l}.27 \\
.41\end{array}$ & $\begin{array}{l}\text { NS } \\
\text { NS }\end{array}$ \\
\hline Populus tremuloides & Quaking aspen & $\begin{array}{l}\text { Age }=(3.96)(\text { Diam })+37.9 \\
\text { Age }=(19.45)(\text { Diam })^{0.61}\end{array}$ & $\begin{array}{l}.70 \\
.82\end{array}$ & $\begin{array}{l}.49 \\
.68\end{array}$ & $\begin{array}{l}.01 \\
.001\end{array}$ \\
\hline Pseudotsuga taxifolia & Douglas fir & $\begin{array}{l}\mathrm{Age}=(15.8)(\mathrm{Diam})+24.8 \\
\mathrm{Age}=(12.13)(\text { Diam })^{1.10}\end{array}$ & .65 & .42 & .025 \\
\hline Quercus gambelii & Gambel oak & $\begin{array}{l}\text { Age }=(12.6)(\text { Diam })+2.71 \\
\text { Age }=(7.94)(\text { Diam })^{1.27}\end{array}$ & $\begin{array}{l}.90 \\
.94\end{array}$ & $\begin{array}{l}.81 \\
.88\end{array}$ & $\begin{array}{l}.005 \\
.001\end{array}$ \\
\hline Tamarix ramosissima & Salt cedar & $\begin{array}{l}\text { Age }=(1.92)(\text { Diam })+5.56 \\
\text { Age }=(6.29)(\text { Diam })^{0.56}\end{array}$ & $\begin{array}{l}.79 \\
.72\end{array}$ & $\begin{array}{l}.62 \\
.52\end{array}$ & $\begin{array}{l}.025 \\
.05\end{array}$ \\
\hline
\end{tabular}

Since the predictive value of the equations varied greatly (Table 4), their value as age-predicting tools depends largely upon the species involved and on the level of precision required for the aging of individual trees. If the need for absolute ages is high, then each tree should be individually aged. However, if gene ral trends and/or patterns are sufficient, so that a certain amount of va riability in absolute ages is acceptable, then the equations become much more useful tools.

In order to gain insight into the age profiles of the different tree species in the Monument, the ages of all 964 individuals sampled were estimated for each diameter class (Table 5). The predicted ages of the several species varied widely, with the oldest trees in the monument being conifers reaching ages of 700 to 900 years. Conversely, the deciduous trees die at much earlier ages, with the oldest trees predicted to be about 125 years.

Upon examination of the population profile data from Utah juniper and pinyon pine (Table 2), it was noted that in 5 of the first 7 diameter classes the ratio of pinyon pine to Utah juniper was near 2. That is, twice as many pinyons were present as junipers. However, in the 2 inch to 6 inch diameter range ( 2 diameter classes) the ratio dropped to 1 . Since the ratio had been near 2 for 300 of the past 400 years and since the trees grow at approximately the same
Table 4. Average percent absolute deviation in years of predicted age from counted age for 8 tree species.

\begin{tabular}{lccc}
\hline \hline & \multicolumn{4}{c}{ Average percent absolute deviation } \\
\cline { 2 - 4 } Species & Mean & $\begin{array}{c}\text { Standard } \\
\text { deviation }\end{array}$ & $\begin{array}{c}\text { Coef. of } \\
\text { variation }\end{array}$ \\
\hline Acer negundo & 181 & 241 & 1.331 \\
Juniperus osteosperma & $16^{2}$ & $21^{2}$ & $1.31^{2}$ \\
& 19 & 13 & .68 \\
Pinus edulis & 19 & 14 & .74 \\
Populus fremontii & 17 & 20 & 1.18 \\
& 14 & 10 & .71 \\
Populus tremuloides & 20 & 14 & .70 \\
& 17 & 11 & .65 \\
Pseudotsuga taxifolia & 38 & 36 & .94 \\
& 26 & 19 & .71 \\
Quercus gambelii & 67 & 73 & 1.10 \\
Tamarix ramosissima & 52 & 61 & 1.17 \\
& 34 & 31 & .91 \\
& 26 & 23 & .88 \\
& 22 & 18 & .82 \\
& 21 & 20 & .94 \\
\hline
\end{tabular}

$1 \%$ Deviation derived from linear age prediction equation.

$2 \%$ Deviation derived from log-log transformed are prediction equation.

Table 5. Mean ages of trees found by diameter class. Ages were determined by the linear prediction equations found in Table 3.

\begin{tabular}{|c|c|c|c|c|c|c|c|c|c|c|c|c|}
\hline & \multicolumn{12}{|c|}{ Diameter class } \\
\hline & 2 & 4 & 6 & 8 & 10 & 12 & 14 & 16 & 18 & 20 & 22 & 24 \\
\hline Acer negundo & 27 & 42 & 61 & 77 & 91 & 112 & 125 & & & & & \\
\hline Juniperus osteosperma & 148 & 193 & 242 & 281 & 329 & 366 & 419 & 462 & 502 & 547 & 594 & 647 \\
\hline Penus edulis & 194 & 237 & 265 & 310 & 343 & 394 & 429 & 485 & 515 & 536 & & \\
\hline Populus fremontii & & 16 & 17 & 18 & 19 & 20 & 22 & 23 & 24 & 25 & 26 & 27 \\
\hline Populus tremuloides & 44 & 49 & 57 & 66 & 74 & 83 & 90 & 97 & 105 & 111 & & \\
\hline Pseudotsuga taxifolia & 38 & 79 & 104 & 139 & 173 & 198 & 235 & 262 & 298 & 326 & 366 & 384 \\
\hline Quercus gambelii & 19 & 40 & 64 & 89 & 122 & & & & & & & \\
\hline Tamarix ramosissima & 94 & 12 & 16 & 19 & 23 & 28 & 30 & 34 & & & & \\
\hline
\end{tabular}




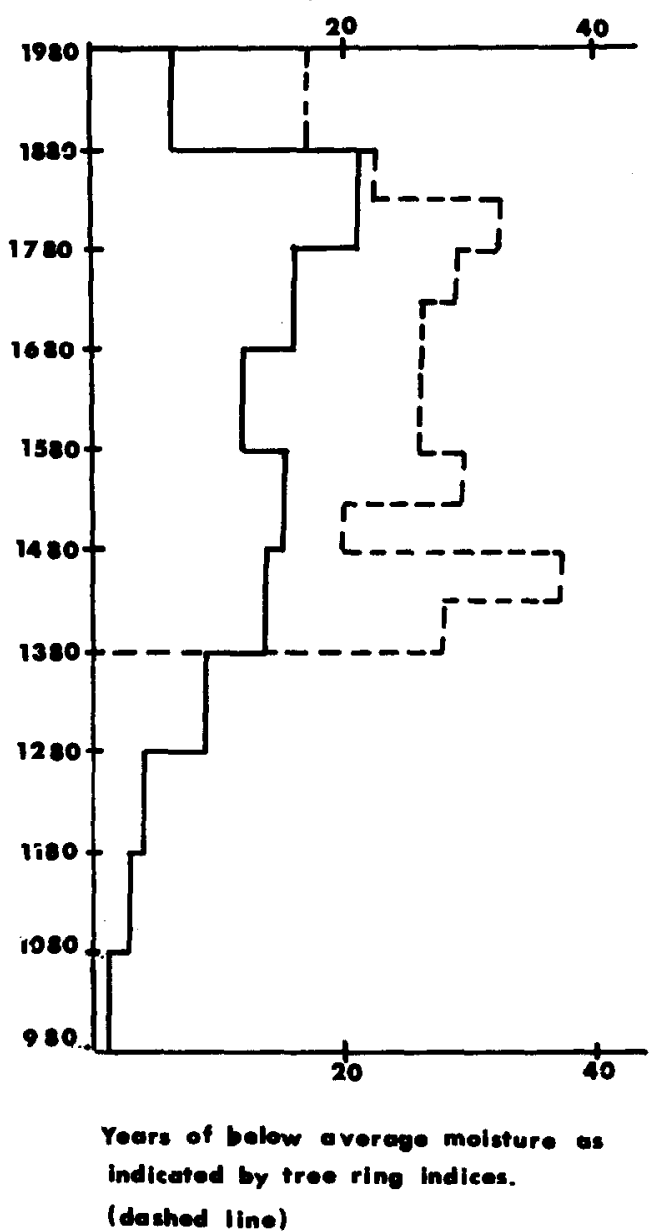

Fig. 4. The relationship of years of below-average moisture as indicated by tree ring indices to the ratio of pinyon to juniper and percent relative densities of pinyon and juniper by age class for the past 600 years.

rate in the area (Table 1), this change in ratio may represent a shift in the past environment of the region toward a drier climate which favored Utah juniper over pinyon pine (West et al. 1979; Wright et al. 1979; Erdman 1970). In an attempt to determine if such a climatic shift had occurred and if it could be correlated to the changes in relative populations of the age classes of the two species, data were obtained from the Laboratory of Tree-Ring Research in Arizona (Dean and Robison 1978). The number of years of belowaverage moisture (as indicated by the tree-ring indices) was determined in 50 year increments. These values are plotted against the pinyon pine to Utah juniper ratios and against the percent relative densities of pinyon pine and Utah juniper in each class (Figure 4). The graphs in Figure 5 represent approximately a 600-year period. There is clearly a peak of years of below average moisture asso-

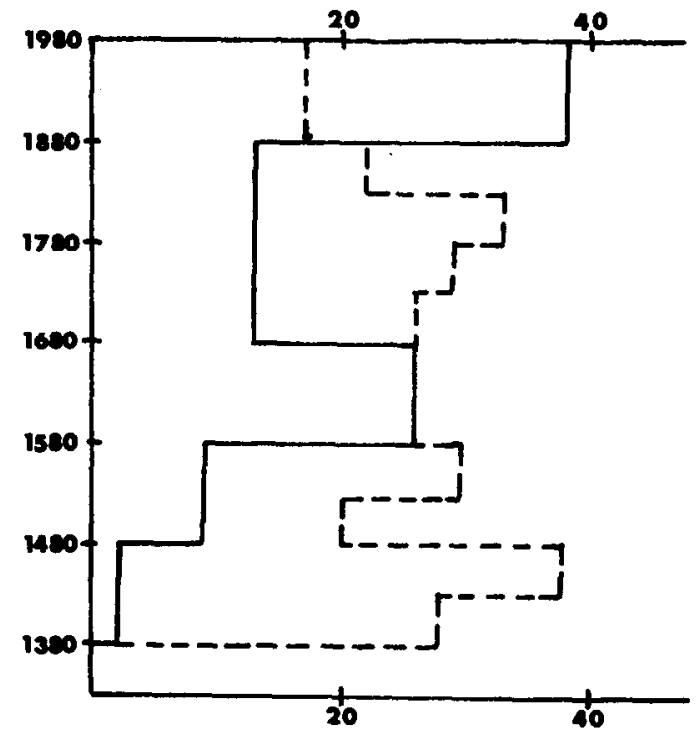

Years of bolow average molsture as indicated by tree ring indices. (dashed line)

RATIO OF PINYON TO JUNIPER IN EACH AGE Class (SOLID LINE)

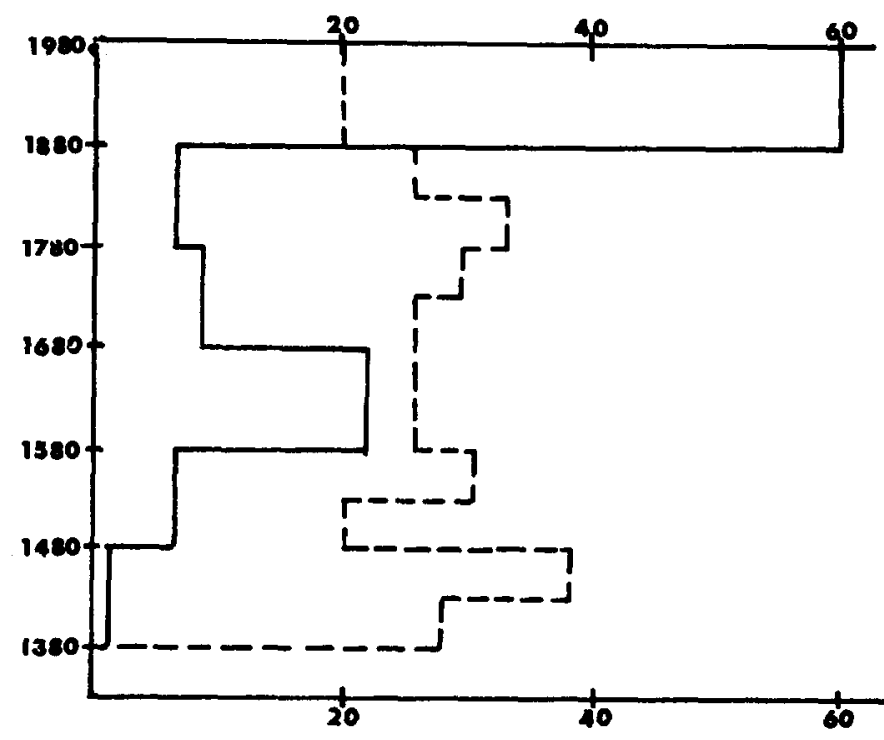

Years below average molsture as

indieated by tree ring indices.

(deshod IIne)

\begin{tabular}{|c|c|c|c|c|c|c|c|c|c|c|c|c|c|}
\hline \multicolumn{14}{|c|}{ Diameter class } \\
\hline 26 & 28 & 30 & 32 & 34 & 36 & 38 & 40 & 42 & 44 & 46 & 48 & 50 & 52 \\
\hline 679 & 730 & 770 & 820 & 869 & & 941 & & & & & & & \\
\hline 28 & 29 & 31 & 31 & & & & & & 37 & & & & \\
\hline 429 & 458 & & 515 & 548 & 570 & 627 & & & & & 760 & 805 & 847 \\
\hline
\end{tabular}


ciated with the intervals of low pinyon pine to Utah juniper ratio (low relative density of pinyon pine by age class and high relative density of Utah juniper by age class). Although these data are only inferential, the relationships suggested are clear enough to merit further study and offer another possibility for research on past climates.

\section{Literature Cited}

Brickell, J.E. 1968. A method for constructing site index curves from measurements of tree age and height-its application to inland Douglas fir. U.S. Forest Service Research Paper INT-47. Intermountain Forest and Range Exp. Sta., Ogden, Utah.

Brotherson, J.D., G. Nebeker, M. Skougard, and J. Fairchild. 1978. Plants of Navajo National Monument. Great Basin Naturalist 38:19-30.

Brotherson, J.D., J.N. Davis, and L. Greenwood. 1980. Diameter-age relationships of two species of Mountain Mahogany. J. Range Manage. 33: 367-370.

Dealy, J.E. 1975. Ecology of curlleaf mountain mahogany (Cercocarpus ledifolius Nutt.) in eastern Oregon and adjacent areas. Unpublished Ph.D. Thesis, Oregon State Univ., Corvallis.

Dean, J.S. and W.J. Robinson. 1978. Expanded tree-ring chronologies for the southwestern United States. Chronology Series III. Laboratory of tree-ring research, Univ. Arizona, Tucson.

Douglas, A.E. 1935. Climatic cycles and tree-growth I: a study of the annual rings of trees in relation to climate and solar activity. Carnegie Institute Washington, Pub. No. 289, Vol. I, Washington.

Ferguson, C.W., and R.R. Humphrey. 1959. Growth rings of big sagebrush reveal rainfall records. Progressive Agriculture in Arizona. 11:3.
Ferguson, C.W. 1970. Concepts and techniques of dendrochronology, p. 183-200. In: R. Berger, ed. Scientific Methods in Medieval Archaeology. UCLA Center for Medieval and Renaissance Studies contributions: IV. Univ. California Press, Berkeley.

Fritts, H.C. 1971. Dendroclimatology and dendroecology. Quaternary Res. 1:419-449.

Fritts, H.C. 1974. Relationships of ring widths in arid-site conifers to variations in monthly temperatures and precipitation. Ecological Monog. 44:411-440.

Glock, W.S. 1937. Principles and methods of tree-ring analysis. Carnegie Institute Washington, Pub. No. 486, Washington.

Harper, K.T. 1979. Dendrochronology-dating with tree rings. In: W.M. Hess and R.T. Matheny, eds., Science and Religion: Towards a More Useful dialogue. Vol 1. Paladin House Publishers, Geneva, Ill.

Jones, J.R. 1969. Review and comparison of site evaluation methods. USDA, Forest Service Res. Pap. RM-51. Rocky Mountain Forest and Range Exp. Sta., Fort Collins, Colo.

McDougall, W.B. 1973. Seed plants of northern Arizona. Museum of Northern Arizona, Flagstaff.

Phillips, E.A. 1959. Methods of vegetation study. Holt, Rinehart and Winston, Inc. New York.

Stage, A.R. 1966. Simultaneous derivation of site-curve and production rating procedures. Proc. Soc. Amer. Foresters 134:136.

Stockton, C.W., and H.C. Fritts. 1973. Long-term reconstruction of water Icvel changes for Lake Athabaska by analysis of tree rings. Water Resources Bull. 9:1006-1027.

Stockton, C.W., and D.M. Meko. 1975. A long-term history of drought occurrence in the western United States as inferred from tree rings. Weatherwise 28:245-249.

Woodbury, A.M. 1963. Biological-ecological aspects of Betatakin Canyon, Navajo National Monument Arizona. Div. Biol. Sciences, Univ. Utah. Misc. Pap. No. 2.

SRM Policy on Section Affillation: When a member moves from one Section to another, he automatically becomes a member of the Section where his new address is. If the member desires to remain a member of his previous Section, he must submit that request in writing to the Denver office.

A member may belong to more than one Section by paying the Section dues for each Section he wishes to be a member of. This must be sent to the Denver office in writing.

Please notify the Denver office concerning change of address as soon as the new address is known. 